\title{
POP UP TOYS AS STORY PLAY THERAPY ON THE LEVEL OF ANXIETY ON GENERAL ANESTHESIA SURGERY AMONG CHILDREN AROUND 6-12 YEARS OLD
}

\author{
Ni Ketut Mendri, Atik Badi’ah, Mohammad Najib \\ School of Health Sciences, Yogyakarta
}

\begin{abstract}
Background: Children who are first hospitalized may experience higher anxiety levels than children who have been hospitalized. The preliminary study in 2018 showed that when general surgery was to be done, as many as 90\%school-age children were scared and nervous. It is important to provide play therapy to children who are going to undergo surgery. In addition to reading and seeing through photos, pop-up toy story books will also be offered to school-age children. This study aimed to examine the relationship between pop up toys as story play therapy on the level of anxiety on general anesthesia surgery among children around 6-12 years old.

Subjects and Method: This was an experimental study with pre-post test with control group design. This study was conducted in Yogyakarta Province hospital. Study subjects were children around 6-12 years old and will performed general anesthesia surgery. The data were collected using questioner and in-depth interview. The data were analyzed using Mann-Whitney test.

Results: There was a decrease number of children with moderate level of anxiety after the intervention group using pop up toys as story play therapy from 30 children $(81.1 \%)$ to 6 children (16.2\%). While in the control group, a total of 25 children had moderate level of anxiety (87.6\%) before the theraphy, and after therapy a total of 2 children also had moderate level of anxiety (5.4\%), and they were statistically significant.

Conclusion: Playing pop up toys story therapy has an effect on the level of anxiety among children around 6-12 years old and will performed general anesthesia surgery.
\end{abstract}

Keywords: pop up toys story therapy, anxiety level, general anesthesia, school age children

Correspondence:

Ni Ketut Mendri. School of Health Sciences, Yogyakarta. Email: mendriniketut@yahoo.com

The $7^{\text {th }}$ International Conference on Public Health

Solo, Indonesia, November 18-19, 2020 | 209

https://doi.org/10.26911/the7thicph.03.29 